\title{
Use of Microalgae to Establish the Trophic Status of Lake La Viña (Argentina)
}

\author{
Rodriguez Claudia ${ }^{1}$, Mancini Miguel ${ }^{1}$, Prosperi Carlos ${ }^{2, *}$ \\ ${ }^{1}$ Ecology, Faculty of Agronomy and Veterinary, National University of Rio Cuarto, Córdoba, Argentina \\ ${ }^{2}$ Blas Pascal University, Environmental Management, Córdoba, and CONICET (National Research Council), Argentina
}

\begin{abstract}
Construction of dams changes physical and chemical characteristics of water basins, producing variations on microalgal community. The Province of Córdoba, located in the Central Region of Argentina, bears more than twenty dams and lakes. One of these lakes is La Viña. The ma in goal of this report was the evaluation of its trophic status using microalgae as bioindicators. Five sampling stations were established. Sample collection was performed monthly and physical and chemical parameters were monitored, according to standard methodology. Results show temporal variations, ranging from mesotrophic to eutrophic, accord ing to weather conditions. Algal bloo ms happened frequently, produced by Cyanophyceae at eutrophic conditions and by Dinophyceae at mesotrophic conditions. Higher levels of chlorophyll "a" occurred during warm months, while lower levels ocurred during the cooler ones. As suggested by our results, urgent actions are required in order to revert this diagnosis and recover a good water quality of the lake.
\end{abstract}

Keywords Cianobacteria, Dinophyceae, Eutrophication, Water Quality

\section{Introduction}

All over the world, the construction of dams for several uses is increasing year after year. This is one of the most important factors influencing changes on the physical and chemical characteristics of water basins.

Lakes and dams are exposed to environmental degradation, as a direct or indirect result of human activities. The growth of human population in the world increased the need for continental water resources, but together with this over-use of water resources, there is also an increasing demand for control and monitoring of the water quality and environmental pollution[1-2]. These changes, in turn, produce variations on the microalgal community, which is very sensitive to conditions of $\mathrm{pH}$, temperature and nutrients concentration. The use of these organisms as bioindicators to evaluate trophic level and other properties related to water quality is based on that fact[3-5].

Microalgae particularly are very sensitive to changes. International standardized protocols were developed in order to detect water contaminants by their effects on microalgae, but it is important to evaluate contaminants over native species in our ecosystems.

An excess of organic matter in water produces eutrophication. This is a process involving important

* Corresponding author:

cprosperi@y ahoo.com.ar (Prosperi Carlos)

Published online at http://journal.sapub.org/als

Copyright (C) 2012 Scientific \& Academic Publishing. All Rights Reserved changes in the normal characteristics of water quality, which may alter the balance between microalgae and zooplanktonic organisms. There are many other wastes that affect in different ways the water balance and stability of ecosystems.

Delivery of to xic chemicals over aquatic bodies produces a variety of complex responses from the organisms involved, affecting existing communities. Considering that lakes and rivers are receiving products from anthropogenic orig in, it is very hard to establish in that mixture which of those products in particular are producing such determined response. When agricultural production is industrialized and intensive, there is an increase in the water demand and resulting wastewaters, loaded with organic matters derived from fertilizers and various biocides

The Province of Córdoba, located in the Central Region of Argentina, bears more than twenty dams and lakes, totalizing a surface of 14.600 ha. Most of these artifitial lakes are suffering serious eutrophication problems because they receive high amounts of untreated water containing nitrogen and phosphorous compounds. This trophic condition is altering the mentioned used of the lakes, especially when it is accompanied with an increase of risky bacteria for human or animal health.

One of these lakes is La Viña, and its uses are wide, serving for touris $m$ and recreation, surfing and sailing, sport fishing, irrigation, reservoir for drinking water and generation of hydroelectricity. There has also been in the past few years a variation in dominance between eutrophication indicating strains of Cianobacteria, like those belonging to the genera Anabaena and Microcystis. 
Preliminary observations have shown that Ceratium hirundinella becomes dominant under mestrophic conditions, while Cyanobacteria in general are do minant under eutrophic to hipertrophic conditions. The trophic status of the lake can oscilate along the year, mainly because it is a turistic area and has a noticiable increase in population during spring and summer months, thus increasing the input of organic matter to the basin.

The main goal of this report was the evaluation of the trophic status of Lake La Viña, using microalgae as bioindicators. Considering that cyanotoxins are present during most of the year, in a dam which is used as a water reservoir for human consumption, the applied interest of this study is more than relevant[6].

\section{Materials and Methods}

Five samp ling stations were established, at the entrance of the rivers into the lake, at the center and exit, and in the areas more frequently used for bathing and recreation[7]. Sample collection was performed monthly. Together with the microscopical study of phytoplankton, physical and chemical parameters were monitored, according to standard methodology[8-9].

Water quality was evaluated according to directions of both the European Community and the US Environmental Protection Agency, together with national regulations.

Bacteriological evaluation: samples were taken in plastic sterile jars at $30 \mathrm{~cm}$. depth and were kept refrigerated until processing. Three samples obtained in 30 days were analyzed, that is, three repetitions for each sampling place at each year station.

Total aerobic microorganisms were evaluated at $37 \mathrm{C}$ (agar plate), total coliforms accord ing to the most probable number technique (MPN / $100 \mathrm{ml}$.) following APHA directions and Colilert analysis test. To search for Streptococcus faecalis, KF Streptococcus agar was employed $(8,9,10)$. Results are expressed as log. (MPN / 100 $\mathrm{ml}+1$ ) or $1 \mathrm{MPN}$.

Phycological evaluation: Samples were obtained in 11 . plastic jars carefully washed in distilled water, at $30 \mathrm{~cm}$. depth. After concentration by decantation, they were fixed with $3 \%$ formaline. Sample counting was made by direct observation, and by means of optical microscopy

Physico-chemical analysis: rinsed glass recipients were used. Samples were obtained also at $30 \mathrm{~cm}$. depth. Physical analysis: smell, turbidity, color, and temperature were evaluated, by standardized methods. Chemical analys is: $\mathrm{pH}$, anions and cations, alkalinity, total salts, arsenic and nitrites were considered.

A non-parametric test equivalent to Student was applied for other variables and ANOVA was calculated with the SPSS for Windows version 9.0 software.

Species were classified by means of identification keys[10-11].

\section{Results}

Results show temporal variations, ranging from mesotrophic during winter and fall, to eutrophic during spring and summer, according to weather conditions, duration of photoperiod, and amount of tourist population.

Algal blooms happened frequently, produced by Cyanophyceae (Microcystis aeruginosa Kutz. Anabaena variabilis, A. spiroides and A. flos-aquae) (Figs 4 and 5) at eutrophyc conditions, and by Dinophyceae (Ceratium hirundinella) (Fig 6) at mesotrophic conditions.

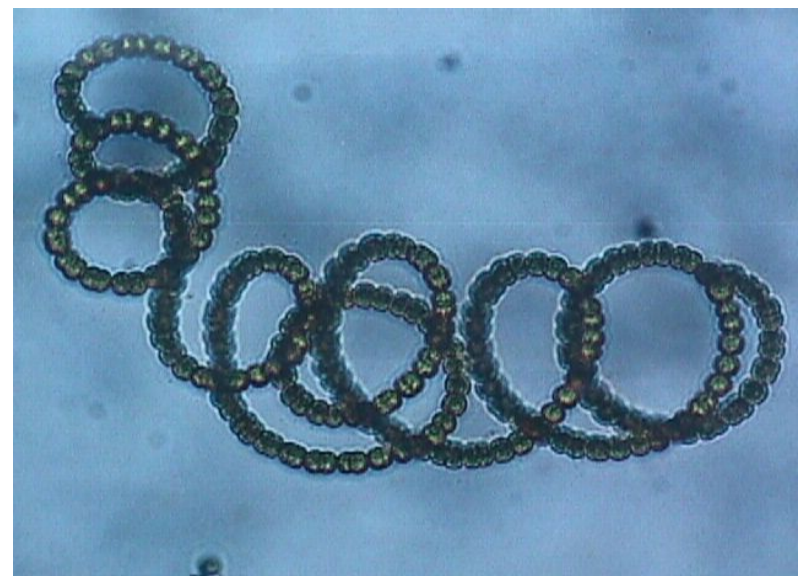

Figure 4. Anabaena spiroides

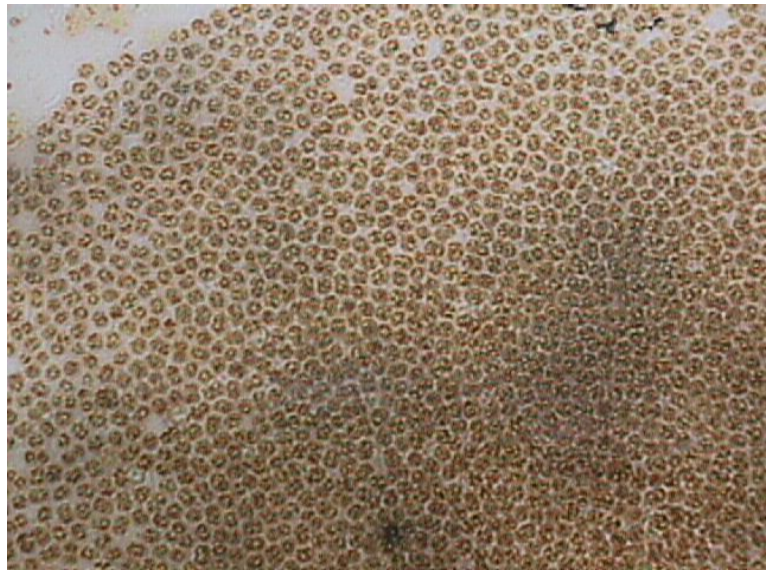

Figure 5. Microcyst is aeruginosa

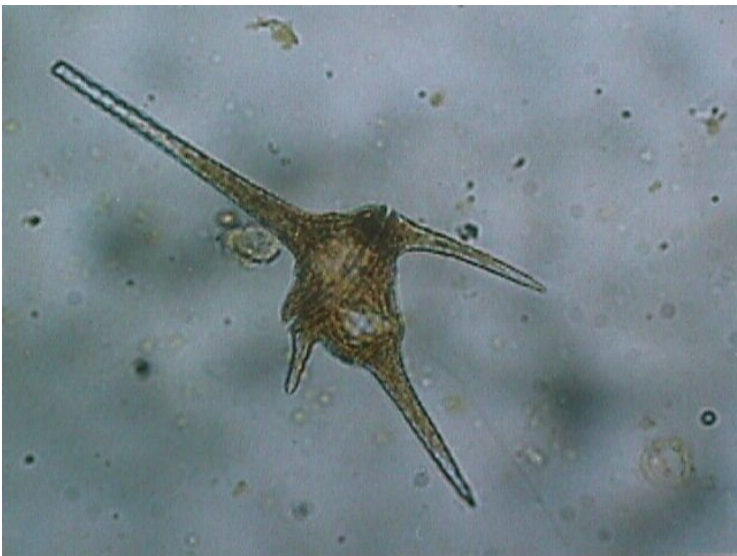

Figure 6. Ceratium hirundinella 
Because of their size or the production of toxins, or a combination of both, these organisms are non-edible for zooplankton and fishes, thus producing important nuisances to the rest of the biota, and even for humans.

It was also observed that Anabaena flos-aquae (Cyanophyceae) formed some smelly blooms, with the characteristics of geosmine production, and probably were related with to xins release too.

All measurements related to the water chemistry oscilated between the admisible limits in this dam, according to both national or international standards.

Coliform bacteria were at low levels in most of the evaluations, although the lake receives municipal waters loaded with foecal matter. In spite of that, Pseudomonas aeruginosa was detected during spring months.

Phytoplanctonic algal diversity was very variable at different seasons, as expected, with higher biomass levels and chlorophyll "a" values during spring and summer months. As water temperature had not important variations from summer to winter, the reported observations should be explained because of the differences in photoperiod duration.

Higher levels of chlorophyll "a" occurred during warm months, while the lower levels occurred during the cooler ones (Figure 1). This fluctuation was als o correlated with the levels of total nitrogen and phosphorous (Figures 2 and 3).

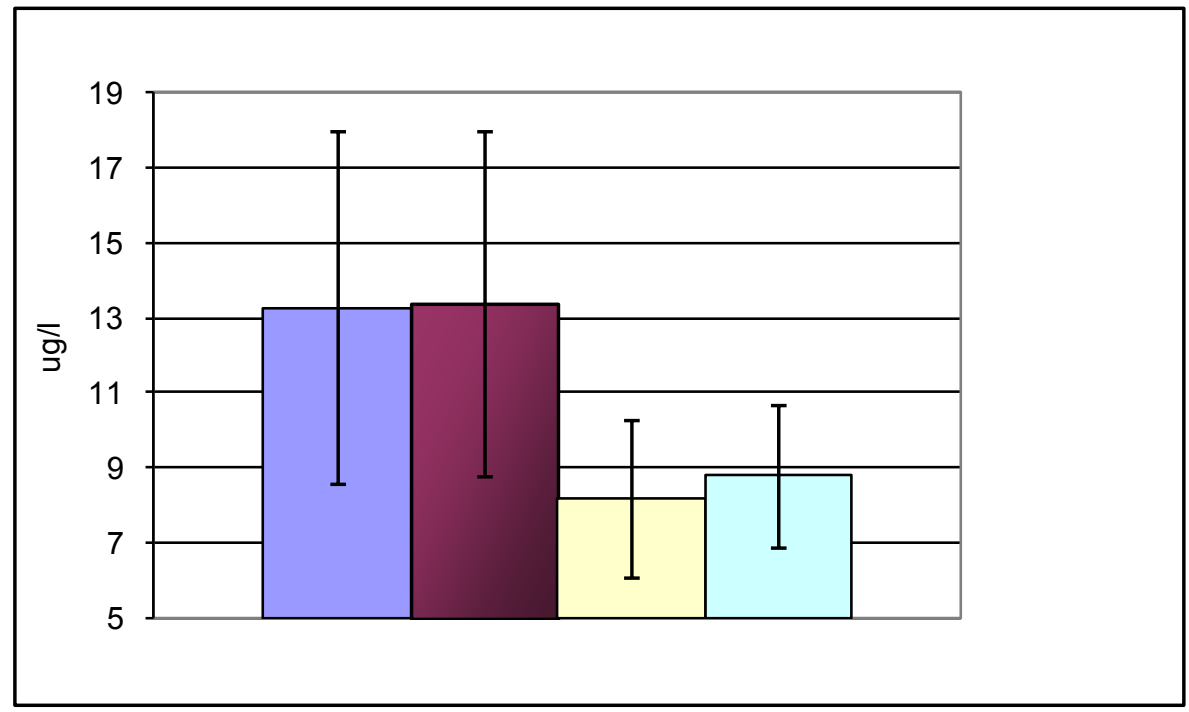

Figure 1. Chlorophyll "a" concentrations. Spring •; Summer •; Fall ; Winter •

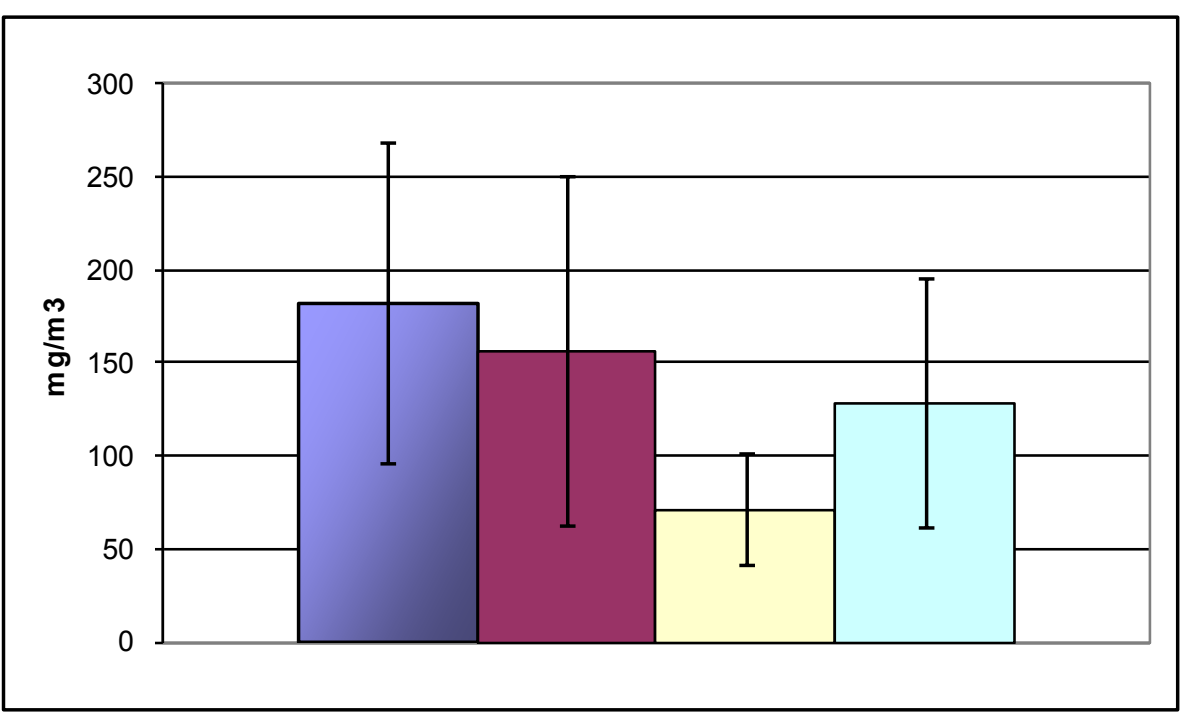

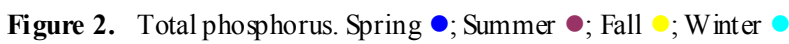




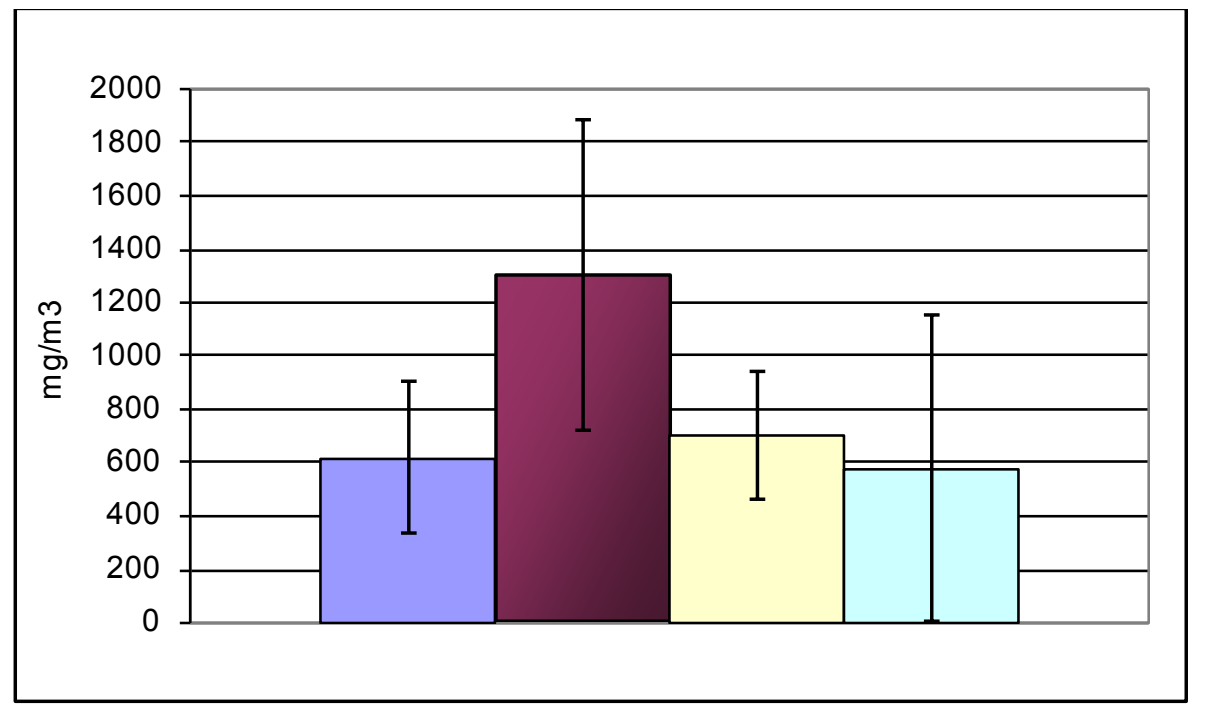

Figure 3. Total Nitrogen. Spring $\bullet$; Summer $\bullet$; Fall $\bullet$; Winter $\bullet$

Our results, based on nutrients concentration (phosphorous and nitrogen) and chlorophill "a" point out that the dam would be placed within a mesotrophic stage moving towards eutrophic.

Thermal stratification of water layers and the increase in organic matter due to algal blooms formed ano xygenic areas at the bottom of the lake, favored also by $\mathrm{pH}$ levels. The months with oxygen deficiency were the most troubled ones for potabilization because of the generation of bad s mells in the treated water.

The lake is characterized by large primary production, low transparency, anaerobic processes in the hypolimnion that generate smelly gases, and recirculation of nutrients with a high charge on organic matter in the input drainages. Measured levels of oxygen concentration are low in general.

\section{Discussion}

Eutrophic conditions, as suggested by chlorophyll levels and dominance of Cianophyceae, occurred usually during summer and spring.

This, of course, could be related to variations in weather conditions, but also to the increase in human population, which is considerable higher during holiday months, as far as the lake is an important tourist resort.

The reverse is observed in winter and fall, with mesotrophic conditions and dominance of Dinophyceae.

As suggested by our results, urgent actions are required in order to revert this diagnosis and recover a good water quality in the lake, not only for environmental reasons but also for the potential danger to human and animal health.

\section{REFERENCES}

[1] D'Angelo R, Ruibal A, Lerda D and Prosperi C (1998) Periodicity and toxin production by Cyanobacteria in an argentinean lake. In: Gokcecus H (1998): Water problems in the mediterranean countries. Vols. 1 and 2: pp 1354. Educational Foundation of Near East University. (Lefkosia ,Chipre). (www.neu.edu.tr).

[2] Lerda D and Prosperi C (1996). Water mutagenicity and toxicology in Rio Tercero (Córdoba, Argentina) Water Research 30 (4): 819-824.

[3] Prosperi C (2000).Cianobacteria in human affaires. Interciencia, Revista de Cien cia y Tecnología de América 25 (6): 303-306.

[4] Rodriguez C, Mancini M, Weyers A and Prosperi C (1998).Algal and microbial variation in lakes of Cordoba (Argentina). In: Gokcecus H (1998): Water problems in the mediterranean countries. Vols. 1 and 2: pp 1354. Educational Foundation of Near East University. (Lefkosia, Chipre). (www.neu.edu.tr).

[5] Whitton B, Rott E and Friedrich G. (1991). Use of algae for monitoring rivers. Univ. Innsbruck.pp 156.

[6] Codd G (1995) Cyanobacterial toxins: Ocurrence, properties and biological significance. Wat. Sci. Tech. 32: 149-156.

[7] Ruibal A, Yamashita N, Tomonari M, Matsui S, Granero M, Yamashiki Y, D'Angelo R and Prosperi C (2001). Phytoplancton variations and toxic Cyanobacterial blooms in San Roque Reservoir (Córdoba, Argentina). Conservation and Management of Lakes 3(1): 59-62.

[8] Stein S (1973). Handbook of phycological methods. Cambridge University Press.Cambridge. pp 445.

[9] USEPA (1968). Water quality criteria. Federal Water Pollution Control Administration. Dep. Of Interior, Washington, pp 7-14.

[10] Bourrely P (1972) Les algues d' eau douce. Ed. Boubee. Paris. Tomes I-III

[11] Desikachary T (1959). Cyanophyta. ICAR. N. Delhi. pp 686. 